\title{
KORELASI INDEKS KOMPRESI (CC) DENGAN PARAMETER SPECIFIC GRAVITY (Gs) DAN INDEKS PLASTISITAS (IP)
}

\author{
Chris Andre Immanuel Berutu1), Niken Silmi Surjandari, ${ }^{2)}$, Noegroho Djarwanti ${ }^{3)}$ \\ 1)Mahasiswa Jurusan Teknik Sipil, Fakultas Teknik, Universitas Sebelas Maret, \\ 2),3) Pengajar Jurusan Teknik Sipil, Fakultas Teknik, Universitas Sebelas Maret \\ Email: andrechris12@yahoo.co.id \\ Jln. Ir. Sutami No. 36A Surakarta 57126
}

\begin{abstract}
Correlation of Compression Index (Cc) with Specific Gravity (Gs) and Plasticity Index (IP) Parameters. Thesis Department of Civil Engineering,Faculty of Engi-neering, Sebelas Maret University Surakarta. Compression index $(C c)$ is one of the parameters that affects the consolidation process, especially in the soft soil layer. To get the parameter of compression index (Cc) laboratory tests are carried out with an oedometer test device. This test requires extra supervision and accuracy, so often using other soil parameters that are easier to determine to find compression indexes. One of them using an empirical formula that has been made by previous researchers such as Naccl et al. (1975) for remolded clays and Rendo-Herrero (1883) for natural clays. The results of the data analyzed by the statistical method produce a compression index equation in East Java it is $C_{c}=0.0076(I P)+0.0435$ and $C c=6,12 \mathrm{E}-05(G s)^{8.3561}$. The best correlation is obtained from the $C_{c}$ equation $=0.0076(I P)+0.0435$ with a correlation coefficient of 0,6521 or 65,21\%. Comparative results show that the compression index equation, $C c=0.0076(I P)+0.0435$ and $C_{c}=6.12 \mathrm{E}-05(G s)^{8.3561}$ produces a smaller value compared to the compression index $(C c)$ of the previous research.
\end{abstract}

Keywords: compression index, specific gravity, plasticity index, statistics

\begin{abstract}
Abstrak
Korelasi Indeks Kompresi (Cc) Dengan Parameter Specific Gravity (Gs) Dan Indeks Plastisitas (Ip). Skripsi Jurusan Teknik Sipil, Fakultas Teknik, Universitas Sebelas Maret Surakarta. Indeks kompresi (Cc) adalah salah satu parameter yang berpengaruh pada proses konsolidasi, terutama pada lapisan tanah lunak. Untuk mendapatkan parameter indeks kompresi (Cc) dilakukan pengujian laboratorium dengan alat uji oedometer. Pengujian ini memerlukan pengawasan dan ketelitian yang ekstra, maka sering menggunakan parameter tanah lainnya yang lebih mudah ditentukan untuk mencari indeks kompresi. Salah satunya menggunakan rumus empiris yang yang telah dibuat oleh para peneliti terdahulu seperti Naccl et al. (1975) untuk lempung yang dibentuk kembali (remolded clays) dan Rendo-Herrero (1883) untuk tanah lempung alami (natural clays). Penelitian ini bertujuan untuk mencari persamaan indeks kompresi (Cc) dengan parameter spesific gravity (Gs) dan indeks plastisitas (IP) dengan menggunakan tanah yang ada di beberapa wilayah di Pulau Jawa. Hasil dari data yang dianalisis dengan metode statistika menghasilkan persamaan indeks kompresi di Jawa Timur sebesar Cc $=0,0076(\mathrm{IP})+0,0435 \mathrm{dan}$ Cc $=6,12 \mathrm{E}-05(\mathrm{Gs})^{8,3561}$. Korelasi terbaik didapatkan dari dari persamaan $\mathrm{Cc}=0,0047(\mathrm{IP})+0,122$ dengan nilai koefisien korelasi sebesar 0,6521 or $65,21 \%$. Hasil komparasi menunjukkan bahwa persamaan indeks kompresi, Cc $=0,0076(\mathrm{IP})+$ 0,0435 dan $\mathrm{Cc}=6,12 \mathrm{E}-05(\mathrm{Gs})^{8,3561}$ menghasilkan nilai yang lebih kecil dibandingkan dengan indeks kompresi (Cc) hasil penelitian sebelumnya.
\end{abstract}

Kata Kunci : indeks kompresi, spesific gravity, indeks plastisitas, statistika

\section{PENDAHULUAN}

Suatu lapisan tanah apabila diatasnya terbebani oleh bangunan konstruksi sipil, akan menyebabkan pemampatan tanah karena air dan udara yang awalnya terdapat dalam pori-pori tanah dipaksa untuk keluar. Hal ini dinamakan dengan konsolidasi tanah. Penurunan konsolidasi tanah merupakan salah satu permasalahan yang sering ditemui dalam bidang geoteknik terutama pada lapisan tanah lunak.

Alat uji oedometer adalah salah satu alat di laboratorium tanah yang digunakan untuk mendapatkan nilai parameter konsolidasi tanah. Pengujian menggunakan alat uji oedometer akan banyak memakan waktu serta diperlukan adanya pengawasan dan ketelitian. Terdapat rumus-rumus empiris yang dapat digunakan untuk memudahkan dalam mencari nilai indeks kompresi (Cc) yang telah dibuat oleh para peneliti terdahulu antara lain Naccl et al. (1975) untuk lempung yang dibentuk kembali (remolded clays), dan Rendo-Herrero (1983) untuk lempung alami (natural clays). Tanah yang digunakan dalam penelitian Naccl dan Rendo lakukan, mempunyai sifat, jenis dan perilaku yang berbeda dengan tanah yang berasal dari di Indonesia, khususnya tanah yang ada di beberapa wilayah di Pulau Jawa. Dari uraian diatas penulis ingin mencari persamaan indeks kompresi (Cc) 
dengan parameter spesific gravity (Gs) dan indeks plastisitas (IP) memakai tanah yang ada di Indonesia, khususnya pulau Jawa.

\section{Landasan Teori}

Indeks plastisitas (IP)

Indeks plastisitas (IP) merupakan interval kadar air dimana tanah masih bersifat plastis. Batas plastis adalah kadar air minimum dimana suatu tanah masih dalam keadaan plastis. Batas plastis ini merupakan batas terendah dari tingkat keplastisan tanah.

\section{Spesific gravity (Gs)}

Spesific gravity adalah perbandingan antara berat butir tanah dengan volume tanah padat atau berat air yang dengan isi sama dengan isi tanah padat tersebut pada suhu tertentu.

\section{Konsolidasi}

Konsolidasi adalah suatu proses pengecilan volume secara perlahan-lahan pada tanah jenuh sempurna dengan permeabilitas rendah akibat pengaliran sebagian air pori. Dengan kata lain, pengertian konsolidasi adalah proses terperasnya air tanah akibat bekerjanya beban, yang terjadi sebagai fungsi waktu karena kecilnya permeabilitas tanah. Proses ini berlangsung terus sampai kelebihan tekanan air pori yang disebabkan oleh kenaikan tegangan total telah benar-benar hilang.

\section{Indeks Kompresi (Cc)}

Indeks kompresi $(\mathrm{Cc})$ adalah nilai parameter suatu tanah yang digunakan untuk memprediksi besarnya penurunan (settlement) tanah yang mengalami pemapatan akibat beban yang terjadi di atasnya. Nilai Cc bisa ditentukan melalui percobaan di laboratorium atau dengan memakai rumus empiris. Adapun beberapa rumus empiris yang sudah ada dari hasil penelitian terdahulu yaitu :

Persamaan Naccl et al. (1975)

Persamaan Rendo-Herrero (1983)

$$
\mathrm{Cc}=0,02(\mathrm{IP})+0,014 \text { (tanah lempung yang dibentuk kembali) }
$$

$$
\mathrm{Cc}=0,141(\mathrm{Gs})^{1,2} \text { (lempung alami) }
$$

\section{Statistik}

Statistik adalah sekumpulan cara maupun aturan-aturan yang berkaitan dengan pengumpulan, pengolahan (analisis), penarikan kesimpulan, atas data-data yang berbentuk angka dengan menggunakan suatu asumsi-asumsi tertentu. (Agus Irianto, 2014)

\section{Analisis Regresi Sederhana}

Analisis regresi merupakan salah satu analisis untuk melihat ada tidaknya hubungan antara variabel bebas dengan variabel terikat.

Persamaan umum regresi sederhana adalah:

$$
\mathrm{Y}=\mathrm{a}+\mathrm{bX}
$$

\section{Dimana :}

$\mathrm{Y} \quad=$ Variabel terikat (dependent variable);

$\mathrm{X} \quad=$ Variabel bebas (independent variable);

a $\quad$ Konstanta;

$\mathrm{b} \quad=$ Koefisien Regresi.

\section{Kurva Non Linier}

Dalam praktek sering dijumpai bahwa sebaran titik-titik data pada suatu grafik tidak membentuk garis lurus (kurva linier) melainkan lebih membentuk garis melengkung (kurva nonlinier). Maka dari itu diperlukan transformasi data agar persamaan regresi linier dapat digunakan untuk mempresentasikan kurva non linier. Persamaan yang dapat digunakan dalam mentransformasi data agar bisa digunakan salah satunya adalah persamaan regresi berpangkat.

Bentuk umum model persamaan regresi berpangkat adalah :

$$
\mathrm{Y}=\mathrm{a} \mathrm{X}^{\mathrm{b}}
$$




\section{Koefisien Korelasi}

Koefisien korelasi adalah nilai yang bertujuan untuk mengukur kuat atau tidaknya hubungan linier antar dua variabel. Persamaan teoritik yang dapat digunakan untuk mengukur hubungan linier antara variabel $\mathrm{X}$ dan $\mathrm{Y}$ adalah koefisien korelasi Pearson (R). Persamaan Pearson sebagai berikut:

$$
r=\frac{n \sum X . Y-\sum X \cdot \sum Y}{\sqrt{\left(n \sum X^{2}-\left(\sum X\right)^{2}\right) \cdot\left(n \sum Y^{2}-\left(\sum Y\right)^{2}\right)}}
$$

$\mathrm{r}$ adalah koefisien korelasi; $\mathrm{n}$ adalah Jumlah data observasi; $\mathrm{X}$ adalah Variabel bebas dan $\mathrm{Y}$ adalah Variabel terikat

\section{Koefisien Determinasi}

Koefisien determinasi merupakan besaran yang akan mengukur ketepatan garis regresi. Koefisien determinasi menunjukkan persentase besarnya variabilitas dalam data yang dijelaskan oleh model regresi. Simbol yang digunakan adalah $R^{2}$. Rumus koefisien determinasi adalah:

$$
R^{2}=\left(\frac{n \sum X \cdot Y-\sum X \cdot \sum Y}{\sqrt{\left(n \sum X^{2}-\left(\sum X\right)^{2}\right) \cdot\left(n \sum Y^{2}-\left(\sum Y\right)^{2}\right)}}\right)^{2}
$$

$\mathrm{R}^{2}$ adalah koefisien determinasi; $\mathrm{n}$ adalah Jumlah data observasi; $\mathrm{X}$ adalah Variabel bebas dan $\mathrm{Y}$ adalah Variabel terikat

\section{Kesalahan Standar Estimasi}

Ketepatan persamaan estimasi dapat dicari dengan mengukur besar kecilnya kesalahan standar estimasi. Semakin kecil nilai kesalahan standar estimasi maka semakin tinggi ketepatan. Kesalahan standar estimasi dapat ditentukan dengan persamaan berikut:

$$
S e=\frac{\sqrt{\sum Y^{2}-a \sum Y-b \sum X . Y}}{n-2}
$$

Se adalah standar estimasi; X adalah Variabel bebas dan Y adalah Variabel terikat; a adalah konstanta; b adalah koefisien regresi; $\mathrm{n}$ adalah jumlah data

\section{Uji t}

Uji t adalah uji yang menilai apakah mean dan keragaman dari dua kelompok berbeda secara statistik satu sama lain. Analisis ini digunakan apabila kita ingin membandingkan mean dan keragaman dari dua kelompok data, dan cocok sebagai analisis dua kelompok rancangan percobaan acak. Untuk menguji hipotesis digunakan statistik yang dihitung dengan cara sebagai berikut:

$$
\begin{gathered}
t_{\text {hitung }}=\frac{b}{S b} \\
S b=\frac{S e^{2}}{\sqrt{\sum X^{2}-\frac{(\Sigma X)^{2}}{n}}}
\end{gathered}
$$

$\mathrm{t}_{\text {hitung }}$ adalah hipotesis yang didapat dari data yang akan dibandingkan dengan $\mathrm{t}$ tabel; $\mathrm{b}$ adalah koefisien regresi; $\mathrm{Sb}$ adalah standar error dari b; Se adalah kesalahan standar estimasi; $\mathrm{x}$ adalah variabel bebas; $\mathrm{n}$ adalah jumlah data.

\section{Pengujian Model}

\section{Uji Normalitas}

Uji normalitas adalah untuk mengetahui apakah suatu distribusi data normal atau tidak. Dengan diketahuinya suatu kelompok data distribusi normal maka estimasi yang kuat sangat mungkin terjadi atau kesalahan mengestimasi dapat diperkecil atau dihindari.Untuk uji keberangkatan data (asal data) dari normalitas digunakan uji Liliefors.

\section{Uji Homogenitas}

Uji asumsi homogenitas merupakan uji perbedaan antara dua kelompok, yaitu dengan melihat perbedaan varians kelompoknya. Pengujian ini dimaksudkan untuk memperlihatkan bahwa dua atau lebih kelompok data sampel berasal dari populasi yang memiliki variansi yang sama. Pengujian homogenitas varians suatu kelompok data, dapat dilakukan dengan cara Uji Fisher.

\section{Uji Asumsi Linieritas}

Asumsi linieritas adalah asumsi yang menyatakan bahwa hubungan antar variabel yang hendak dianalisis itu mengikuti garis lurus. Artinya, peningkatan atau penurunan kualitas di satu variabel, akan diikuti secara linier oleh peningkatan atau penurunan kualitas di variabel yang lainnya. 


\section{HASIL DAN PEMBAHASAN}

Persamaan Regresi Linier Antara Cc Laboratorium dan IP di Jawa Timur

Data-data sekunder yang telah di dapatkan di seleksi dan di kumpulkan kedalam tabel 1.

Tabel 1. Perhitungan regresi sederhana antara $C_{c}$ laboratorium dengan IP di Jawa Timur

\begin{tabular}{|c|c|c|c|c|c|}
\hline NO & $\begin{array}{c}\text { Indeks } \\
\text { plastisitas } \\
(\mathrm{X})\end{array}$ & $\begin{array}{c}\text { Indeks } \\
\text { Kompresi } \\
(\mathrm{Y})\end{array}$ & $\mathbf{X}^{2}$ & $\mathbf{Y}^{2}$ & X.Y \\
\hline 1 & 18,45 & 0,275 & 340,40 & 0,076 & 5,0738 \\
\hline 2 & 19,48 & 0,18 & 379,51 & 0,031 & 3,4287 \\
\hline 3 & 23,07 & 0,323 & 532,42 & 0,104 & 7,4530 \\
\hline 4 & 24,65 & 0,38 & 607,62 & 0,141 & 9,2684 \\
\hline 5 & 29,74 & 0,20 & 884,47 & 0,040 & 5,9480 \\
\hline 6 & 48,65 & 0,34 & 2366,82 & 0,115 & 16,4924 \\
\hline 7 & 35,81 & 0,24 & 1282,36 & 0,059 & 8,7018 \\
\hline 8 & 24,42 & 0,34 & 596,34 & 0,114 & 8,2330 \\
\hline 9 & 31,11 & 0,22 & 967,83 & 0,049 & 6,9096 \\
\hline 10 & 72,15 & 0,96 & 5204,95 & 0,913 & 68,9291 \\
\hline 11 & 33,45 & 0,43 & 1118,87 & 0,187 & 14,4837 \\
\hline 12 & 32,95 & 0,19 & 1086,02 & 0,037 & 6,3603 \\
\hline 13 & 27,39 & 0,29 & 750,21 & 0,082 & 7,8609 \\
\hline 14 & 24,64 & 0,18 & 607,13 & 0,033 & 4,4971 \\
\hline 15 & 40,57 & 0,26 & 1645,92 & 0,067 & 10,4671 \\
\hline 16 & 24,99 & 0,23 & 624,50 & 0,052 & 5,6977 \\
\hline 17 & 29,35 & 0,20 & 861,42 & 0,040 & 5,8407 \\
\hline 18 & 24,87 & 0,19 & 618,52 & 0,035 & 4,6756 \\
\hline 19 & 57,98 & 0,335 & 3361,68 & 0,112 & 19,4233 \\
\hline 20 & 47,95 & 0,402 & 2299,20 & 0,162 & 19,2759 \\
\hline 21 & 53,87 & 0,270 & 2901,98 & 0,073 & 14,5449 \\
\hline 22 & 34,54 & 0,234 & 1193,01 & 0,055 & 8,0824 \\
\hline 23 & 19,70 & 0,320 & 388,09 & 0,102 & 6,3040 \\
\hline 24 & 26,81 & 0,198 & 718,78 & 0,039 & 5,3084 \\
\hline$\sum$ & 806,60 & 7,17 & 31338,06 & 2,72 & 273,26 \\
\hline
\end{tabular}

Dari tabel 1 di atas, di dapatkan model diagram pencarnya yaitu:

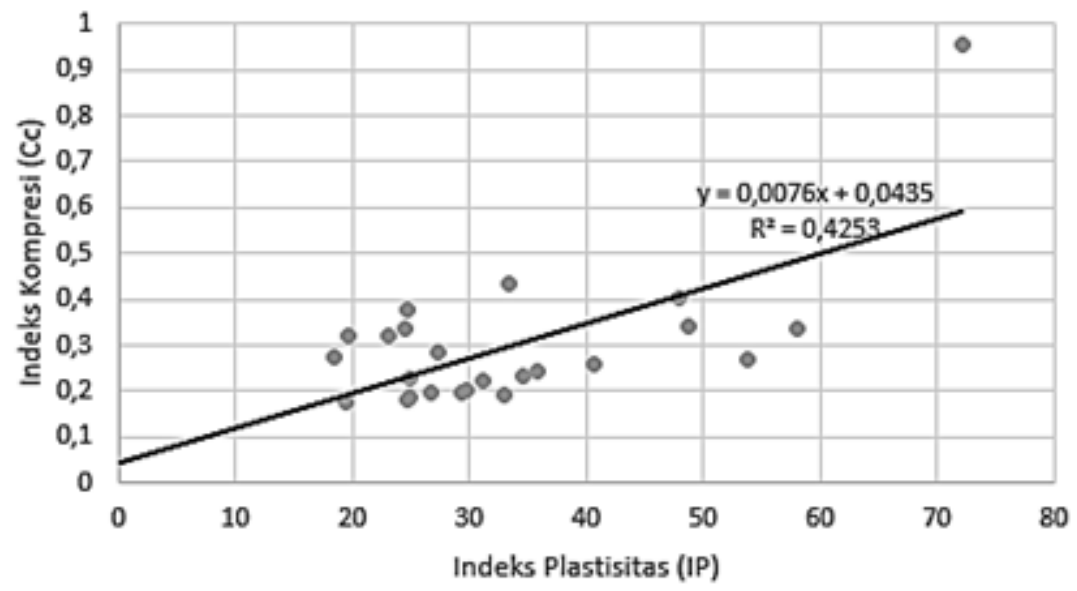

Gambar 1. Diagram pencar indeks kompresi $\left(C_{c}\right)$ laboratorium dan indeks plastisitas (IP) di Jawa Timur

Dari diagram pencar didapatkan model regresi linier Cc dan IP di Jawa Timur adalah Cc $=0,0076$ (IP) $+0,0435$ dengan koefisien determinasi sebesar 0,4253. Sedangkan koefisien korelasinya dihitung menggunakan persamaan koefisien korelasi di dapat koefisien korelasi sebesar 0,6521. 
Persamaan Regresi Berpangkat Antara $\mathrm{C}_{\mathrm{c}}$ Laboratorium dan GS di Jawa Timur

Tabel 2. Perhitungan regresi berpangkat antara $C_{c}$ laboratorium dengan $G s$ di Jawa Timur

\begin{tabular}{cccccccc}
\hline NO & $\begin{array}{c}\text { Specific } \\
\text { Gravity } \\
(\mathbf{X})\end{array}$ & $\begin{array}{c}\text { Indeks } \\
\text { Kompresi } \\
(\mathbf{Y})\end{array}$ & $\mathbf{P}=\mathbf{l o g} \mathbf{X}$ & $\mathbf{Q}=\mathbf{l o g} \mathbf{Y}$ & $\mathbf{X}^{2}$ & $\mathbf{Y}^{\mathbf{2}}$ & $\mathbf{X . Y}$ \\
\hline 1 & 2,660 & 0,176 & 0,425 & $-0,754$ & 0,181 & 0,569 & $-0,321$ \\
\hline 2 & 2,740 & 0,364 & 0,438 & $-0,439$ & 0,192 & 0,193 & $-0,192$ \\
\hline 3 & 2,720 & 0,201 & 0,435 & $-0,697$ & 0,189 & 0,486 & $-0,303$ \\
\hline 4 & 2,730 & 0,200 & 0,436 & $-0,699$ & 0,190 & 0,489 & $-0,305$ \\
\hline 5 & 2,700 & 0,339 & 0,431 & $-0,470$ & 0,186 & 0,221 & $-0,203$ \\
\hline 6 & 2,700 & 0,242 & 0,431 & $-0,616$ & 0,186 & 0,380 & $-0,266$ \\
\hline 7 & 2,730 & 0,243 & 0,436 & $-0,614$ & 0,190 & 0,377 & $-0,268$ \\
\hline 8 & 2,730 & 0,302 & 0,436 & $-0,520$ & 0,190 & 0,270 & $-0,227$ \\
\hline 9 & 2,630 & 0,222 & 0,420 & $-0,653$ & 0,176 & 0,427 & $-0,274$ \\
\hline 10 & 2,680 & 0,300 & 0,428 & $-0,523$ & 0,183 & 0,273 & $-0,224$ \\
\hline 11 & 2,660 & 0,193 & 0,425 & $-0,714$ & 0,181 & 0,510 & $-0,304$ \\
\hline 12 & 2,680 & 0,185 & 0,428 & $-0,733$ & 0,183 & 0,537 & $-0,314$ \\
\hline 13 & 2,680 & 0,287 & 0,428 & $-0,542$ & 0,183 & 0,294 & $-0,232$ \\
\hline 14 & 2,66 & 0,18 & 0,425 & $-0,745$ & 0,181 & 0,555 & $-0,316$ \\
\hline 15 & 2,700 & 0,258 & 0,431 & $-0,588$ & 0,186 & 0,346 & $-0,254$ \\
\hline 16 & 2,710 & 0,228 & 0,433 & $-0,642$ & 0,187 & 0,412 & $-0,278$ \\
\hline 17 & 2,730 & 0,199 & 0,436 & $-0,701$ & 0,190 & 0,492 & $-0,306$ \\
\hline 18 & 2,690 & 0,188 & 0,430 & $-0,726$ & 0,185 & 0,527 & $-0,312$ \\
\hline 19 & 2,710 & 0,402 & 0,433 & $-0,396$ & 0,187 & 0,157 & $-0,171$ \\
\hline 20 & 2,670 & 0,234 & 0,427 & $-0,631$ & 0,182 & 0,398 & $-0,269$ \\
\hline 21 & 2,710 & 0,264 & 0,433 & $-0,578$ & 0,187 & 0,335 & $-0,250$ \\
\hline 22 & 2,690 & 0,320 & 0,430 & $-0,495$ & 0,185 & 0,245 & $-0,213$ \\
\hline 23 & 2,710 & 0,247 & 0,433 & $-0,607$ & 0,187 & 0,369 & $-0,263$ \\
\hline 24 & 2,650 & 0,198 & 0,423 & $-0,703$ & 0,179 & 0,495 & $-0,298$ \\
\hline$\sum$ & 64,670 & 5,972 & 10,331 & $-14,788$ & 4,448 & 9,355 & $-6,361$ \\
\hline & & & & & & & \\
\hline
\end{tabular}

Untuk pengerjaan regresi berpangkat, data - data yang ada di transformasi menjadi data log terlebih dahulu untuk medapatkan model regresi linier pada regresi berpangkat.

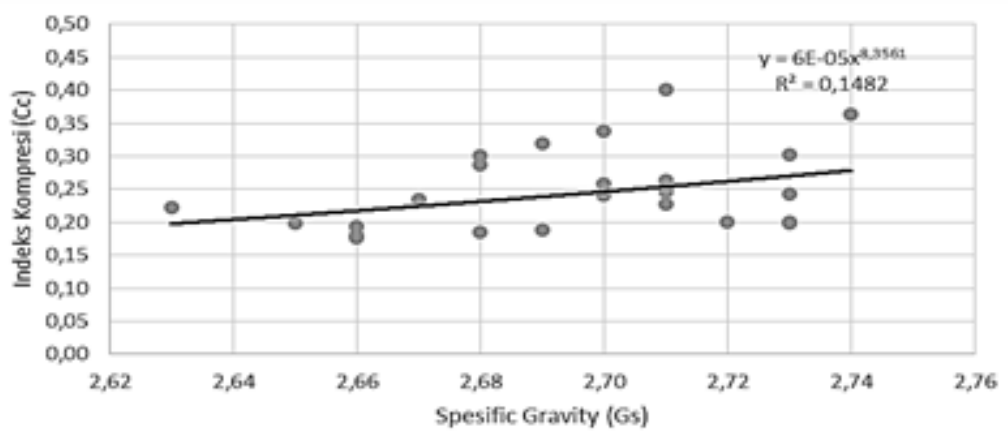

Gambar 2. Diagram pencar indeks kompresi $\left(C_{c}\right)$ laboratorium dan spesific gravity $(G s)$ data model regresi berpangkat di Jawa Timur

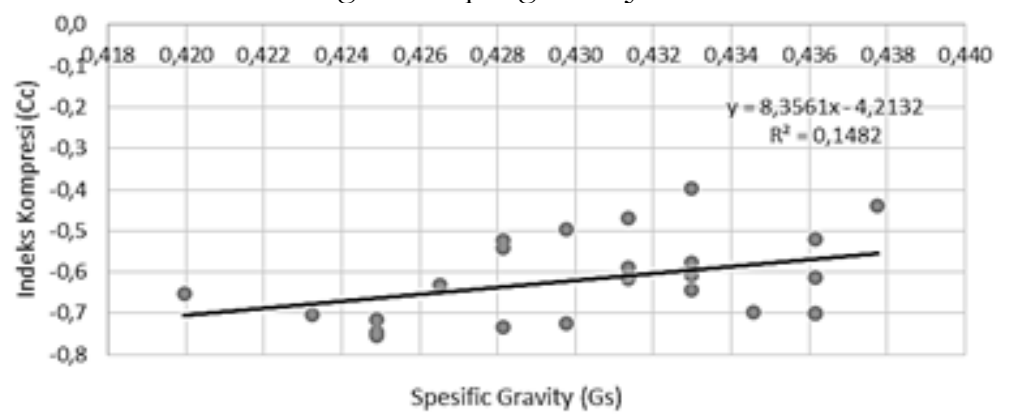

Gambar 3. Diagram pencar indeks kompresi $\left(C_{c}\right)$ laboratorium dan spesific gravity (Gs) model regresi berpangkat yang telah dilinier-kan di Jawa Timur 
Dari diagram pencar pada gambar 3 didapatkan model regresi linier Cc dan Gs di Jawa Timur adalah Cc $=8,3561$ (Gs) - 4,2132 dan untuk model linier berpangkat nya dapat di lihat pada gambar 2 sebesar Cc $=6 \times 10^{-5}(\mathrm{Gs})^{8,3561}$. koefisien determinasi yang di dapat sebesar 0,1482. Sedangkan koefisien korelasinya dihitung menggunakan persamaan koefisien korelasi sebesar 0,3849 .

Tabel 3. Rekapitulasi Persamaan Regresi, koefisien korelasi, koefisien determinasi, dan standar estimasi

\begin{tabular}{llccc}
\hline \multicolumn{1}{c}{ Data Uji } & \multicolumn{1}{c}{ Persamaan Regresi } & $\begin{array}{c}\mathbf{r} \\
\mathbf{( \% )}\end{array}$ & $\begin{array}{c}\mathbf{R}^{\mathbf{2}} \\
\mathbf{( \% )}\end{array}$ & Se \\
\hline Cc dan IP di Jawa Timur & $\mathrm{Cc}=0,0076(\mathrm{IP})+0,0435$ & 65,21 & 42,526 & 0,0261 \\
\hline Cc dan Gs di Jawa Timur & $\mathrm{Cc}=6,12 \mathrm{E}-05(\mathrm{Gs})^{8,3561}$ & 38,49 & 14,82 & 0,0207 \\
\hline
\end{tabular}

Berdasarkan Tabel 3 persamaan regresi antara indeks kompresi (Cc) laboratorium dan indeks plastisitas (IP) di Jawa Timur yaitu Cc $=0,0076($ IP) + 0,0435 yang mempunyai koefisien korelasi (r) sebesar 65,21\% dan koefisien determinasi $\left(\mathrm{R}^{2}\right)$ sebesar 42,526\% dengan tingkat kesalahan sebesar 0,0261. Hal ini menunjukkan bahwa persamaan indeks kompresi dan indeks plastisitas di Jawa Timur mempunyai hubungan yang kuat dengan tingkat kesalahan yang sangat kecil.

Pada persamaan indeks kompresi (Cc) laboratorium dengan spesific grafity (Gs) yaitu Cc $=6,12 \mathrm{E}-05$ $(\mathrm{Gs})^{8,3561}$ yang mempunyai koefisien korelasi sebesar 38,49\% dan koefisien determinasi 14,82\% dengan tingkat kesalahan sebesar 0,0207. Menurut Sugiyono (2010) koefisien korelasi antara 0,20-0,399 dikatakan rendah sehingga persamaan regresi antara Cc dan Gs di Jawa Timur tidak cukup kuat untuk dijadikan sebagai acuan.

\section{Uji Asumsi Parametik}

Tabel 4. Rekapitulasi Uji t, Uji Homogenitas, Uji Linieritas, Uji Normalitas

\begin{tabular}{|c|c|c|c|c|c|}
\hline \multirow[b]{2}{*}{ Data Uji } & \multirow[b]{2}{*}{$\begin{array}{l}\text { Uji Parsial } \\
\text { (Uji t) }\end{array}$} & \multirow[b]{2}{*}{$\begin{array}{c}\text { Uji } \\
\text { Homogenitas }\end{array}$} & \multirow[b]{2}{*}{ Uji Linieritas } & \multicolumn{2}{|c|}{ Uji Normalitas } \\
\hline & & & & $\begin{array}{c}\text { Variabel } \\
\text { Bebas (X) }\end{array}$ & $\begin{array}{c}\text { Variabel } \\
\text { Terikat (Y) }\end{array}$ \\
\hline Cc dan IP di Jawa & & $F_{\text {bitung }}>F_{\text {tabel }}$ & $F_{\text {hitung }}<F_{\text {tabel }}$ & $D_{\text {bitung }}<D_{\text {tabel }}$ & $D_{\text {bitung }}<D_{\text {tabel }}$ \\
\hline Timur & 10,024 & $85,8018>4,28$ & $5,4875<248,309$ & $0,1806<0,1809$ & $0,1804<0,1809$ \\
\hline Cc dan Gs di Jawa & $t_{\text {bitung }}>t_{\text {tabel }}$ & $F_{\text {bitung }}>F_{\text {tabel }}$ & $\mathrm{F}_{\text {hitung }}<\mathrm{F}_{\text {tabel }}$ & $D_{\text {bitung }}<D_{\text {tabel }}$ & $D_{\text {bitung }}<D_{\text {tabel }}$ \\
\hline Timur & $9,1764>2,074$ & $21,706>4,28$ & $1,757<2,7144$ & $0,0891<0,1809$ & $0,1585<0,1809$ \\
\hline
\end{tabular}

Berdasarkan Tabel 4 terlihat bahwa semua hasil uji menunjukkan hal yang serupa untuk semua data uji. Uji Parsial (uji t) menunjukkan hasil thitung dari semua data uji adalah lebih kecil dari pada tabel yang artinya Ho ditolak dan Ha diterima. Menurut hipotesis statistik uji t jika Ho ditolak dan Ha diterima maka ada pengaruh yang signifikan antara variabel bebas dan variabel terikat, dimana di sini variabel bebas adalah indeks plastisitas (IP) dan spesific gravity (Gs), sedangkan variabel terikatnya adalah indeks kompresi (Cc). Jadi indeks plastisitas (IP) dan spesific gravity (Gs) mempunyai pengaruh yang signifikan terhadap hasil dari indeks kompresi (Cc). Kondisi ini sesuai dengan teori geoteknik, Naccl et al. (1975) dan Rendo-Herrero (1883) yang apabila tanah semakin cair maka akan semakin besar nilai penurunannya.

Uji homogenitas menunjukkan hasil $F_{\text {hitung }}$ dari semua data uji adalah lebih besar dari $F_{\text {tabel }}$ yang artinya Ho ditolak dan Ha diterima. Menurut hipotesis statistik uji homogenitas, Ho mewakili varians yang homogen dan $\mathrm{Ha}$ mewakili varians yang tidak homogen. Jadi antara indeks kompresi, indeks plastisitas dan spesific gravity merupakan varians yang tidak homogen.

Uji linieritas menunjukkan hasil $F_{\text {hitung }}$ dari semua data uji adalah lebih kecil dari $F_{\text {tabel yang artinya ada }}$ hubungan yang liniear secara signifikan antara variabel bebas dan variabel terikat. Sehingga model linier dari persamaan regresi yang ada dapat di terima.

Uji normalitas menunjukkan Dhitung dari semua data yang di ujikan adalah lebih kecil dari Dtabel, yang artinya Ho diterima dan Ha ditolak. Menurut hipotesis statitik uji normalitas, Ho mewakili data yang berdistribusi normal dan Ha mewakili data yang berdistribusi tidak normal. Jadi data yang telah di ujikan berdistribusi normal.

\section{Komparasi Dengan Penelitian Terdahulu}

Komparasi terhadap penelitian sebelumnya dilakukan untuk melihat seberapa dekat atau jauh hasil penelitian ini dengan hasil penelitian sebelumnya. Data yang digunakan untuk komparasi dengan penelitian sebelumnya ini merupakan data dari sisa data pembuatan model persamaan regresi linier sederhana. Data yang digunakan untuk verifikasi ini adalah sebanyak 1/3 dari jumlah data yang ada. Data yang digunakan dipilih secara acak. Komparasi hasil dari perhitungan dalam penelitian ini akan dibandingkan dengan penelitian sebelumnya, seperti Naccl et al 
(1975) untuk indeks plastisitas (IP) dan Rendo-Herrero (1983) untuk spesific gravity (Gs).

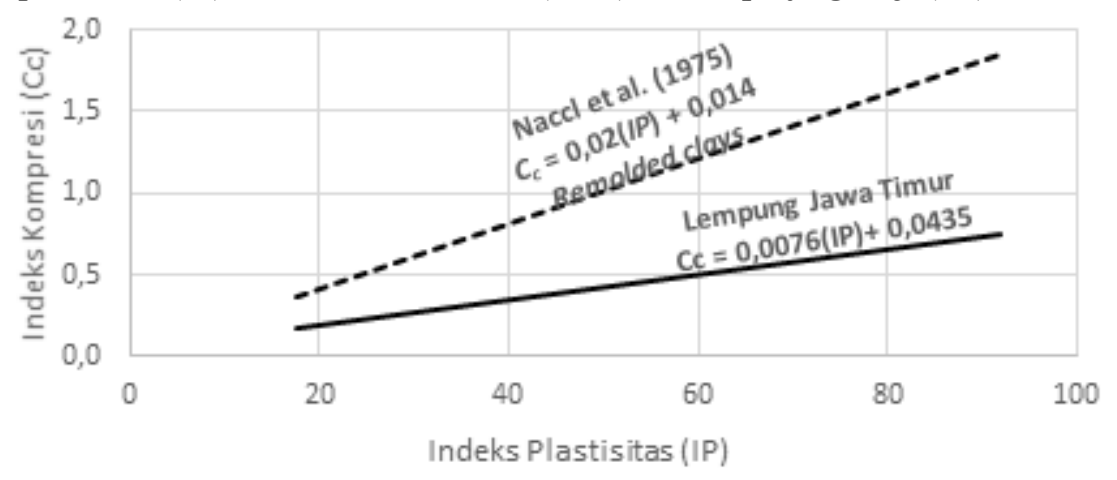

Gambar 4. Komparasi indeks kompresi $\left(C_{c}\right)$ terhadap parameter indeks plastisitas $(I P)$

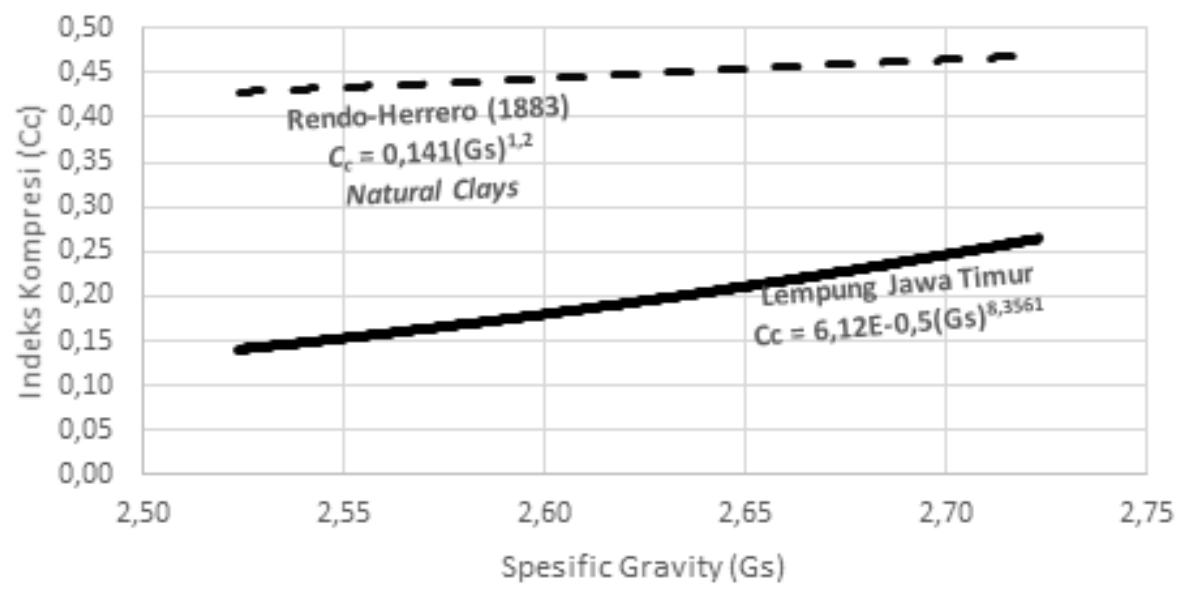

Gambar 5. Komparasi indeks kompresi $\left(C_{c}\right)$ terhadap parameter spesific gravity $(G s)$

Hasil komparasi terhadap peneliti terdahulu dapat dilihat dari Gambar 4 untuk Cc terhadap IP dan Gambar 5 untuk Cc terhadap Gs. Perilaku persamaan regresi peneliti terdahulu pada grafik tersebut menunjukkan perilaku yang sama terhadap perilaku persamaan regresi penelitian ini, yaitu semakin tinggi indeks plastisitas maupun spesific gravity semakin tinggi pula indeks kompresinya. Perbedaan yang membuat perilaku persamaan regresi penelitian ini berada dibawah persamaan regresi penelitian terdahulu dapat disebabkan oleh berbagai hal, antara lain jenis dan sifat tanah yang di uji dalam penelitian terdahulu berbeda dengan penelitian ini, perbedaan banyaknya sampel dari penelitian terdahulu dan penelitian ini, dan perilaku tanah yang dapat juga berbeda.

\section{KESIMPULAN}

1. Hasil dari analisa regresi mendapatkan persamaan indeks kompresi (Cc) terhadap indeks plastisitas (IP) yaitu $\mathrm{Cc}=0,0076(\mathrm{IP})+0,0435$; koefisien korelasi $(\mathrm{r})=65,21 \%$; koefisien determinasi $\left(\mathrm{R}^{2}\right)=42,526 \%$; dan standar estimasi $(\mathrm{Se})=0,02612$. Dari hasil analisis menunjukkan bahwa persamaan regresi antara indeks kompresi (Cc) terhadap indeks plastisitas (IP) di Jawa Timur mempunyai nilai korelasi yang kuat dan koefisien determinasi yang relatif baik dengan tingkat kesalahan standar estimasi yang kecil mendekati nilai 0 .

2. Hasil dari analisa regresi mendapatkan persamaan indeks kompresi (Cc) terhadap spesific gravity (Gs) yaitu Cc $=6,12 \mathrm{E}-05(\mathrm{Gs})^{8,3561}$; koefisien korelasi $(\mathrm{r})=38,49 \%$; koefisien determinasi $\left(\mathrm{R}^{2}\right)=14,82 \%$; dan standar estimasi $(\mathrm{Se})=0,0207$. Dari hasil analisis menunjukkan bahwa persamaan regresi antara indeks kompresi (Cc) terhadap spesific gravity (Gs) di Jawa Timur mempunyai nilai korelasi yang rendah dan koefisien determinasi yang tidak baik dengan tingkat kesalahan standar estimasi yang kecil mendekati nilai 0 . Sehingga untuk model persamaan regresi indeks kompresi (Cc) terhadap spesific gravity (Gs) di Jawa Timur tidak di anjurkan untuk di jadikan sebagai acuan.

3. Pengujian hipotesis dengan uji t menyatakan bahwa ada pengaruh yang signifikan antara indeks kompresi (Cc) dan indeks plastisitas (IP) dan spesific gravity (Gs).

4. Uji normalitas menunjukkan semua data yang di ujikan berdistribusi normal.

5. Uji homogenitas menunjukkan bahwa semua data yang di dapat tidak menunjukkan ke homogenitasan. 
6. Uji linieritas menunjukkan bahwa semua model linier yang di buat dapat diterima.

7. Hasil komparasi persamaan yang di dapat yaitu $\mathrm{Cc}=0,0076(\mathrm{IP})+0,0435$ memberikan nilai indeks kompresi (Cc) yang lebih kecil dibandingkan dengan persamaan Cc $=0,02(\mathrm{IP})+0,014$ milik Naccl et all (1975) untuk tanah lempung yang dibentuk kembali

8. Hasil komparasi persamaan yang didapat yaitu $\mathrm{Cc}=6,12 \mathrm{E}-05(\mathrm{Gs})^{8,3561}$ juga memberikan nilai indeks kompresi $(\mathrm{Cc})$ yang lebih kecil dibandingkan dengan persamaan $\mathrm{Cc}=0,141(\mathrm{Gs})^{1,2}$ milik Rendo-Herrero (1883) untuk lempung alami.

\section{REKOMENDASI}

Berdasarkan hasil penelitian, maka perlu adanya penelitian lanjut untuk menyempurnakan dan mengembangkan tema penelitian ini, diantaranya adalah :

1. Mencari persamaan rumus empiris indeks kompresi (Cc) dengan parameter indeks plastisitas (IP), kadar air alamiah (wn), batas cair (LL), angka pori awal ( $\left.\mathrm{e}_{0}\right)$, dan spesific gravity $(\mathrm{Gs})$ untuk wilayah lainnya di Indonesia seperti di Papua atau di Sulawesi.

2. Untuk koefisien korelasi ( $r$ ) dan koefisien determinasi $\left(R^{2}\right)$ yang tidak baik yaitu $r<0,399$ dan $R^{2}<25 \%$ sebaiknya dilakukan penambahan data untuk menaikkan angka koefisiennya.

3. Untuk data - data yang asumsi normalitas tidak terpenuhi, sebaiknya dilakukan transformasi data atau melakukan uji alternatif dengan uji non parametris, misalnya uji mann whitney u test.

4. Untuk data-data yang tidak homogen sebaiknya dilakukan pengujian lain untuk menguji homogenitas suatu data. Misalkan pada uji Anova, jika asumsi homogenitas tidak terpenuhi, maka peneliti dapat menggunakan koreksi oleh uji brown forsythe atau welch's F. Sedangkan jika asumsi homogenitas tidak terpenuhi pada uji independen $t$ test, peneliti dapat menggunakan uji independen $t$ test unequal variance atau menggunakan uji indepeden welch's test.

\section{UCAPAN TERIMAKASIH}

Puji syukur kepada Tuhan Yang Maha Esa, sehingga penelitian ini dapat terselesaikan. Ucapan terima kasih juga kami sampaikan kepada Dr. Niken Silmi Surjandari ST MT dan Ir. Noegroho Djarwanti MT atas bimbingan, arahan, dan koreksinya dalam penelitian ini. Pada kesempatan ini kami mengucapkan terima kasih yang tulus kepada semua pihak yang telah berperan dalam mewujudkan penelitian ini secara langsung maupun tidak langsung khususnya mahasiswa sipil UNS 2012.

\section{REFERENSI}

Azzouz.,A.S., R. J. Krizek, and R. B. Corotis,(1976), “Regression Analysis of Soil Compressibility”, Soils and Foundations,

Djarwanti, Noegroho. (2006). "Karakteristik Lempung Grobogan terhadap Persamaan Empirik Indeks Pemampatan". Surakarta: Media Teknik Sipil UNS.

Gunawan, Andrieas.(2013)“Bab III - Konsolidasi dan Penurunan”. http://andrieasgunawan.blogspot.co.id/2013/03/mekanika-tanah-2- konsolidasi-dan.html (7 Desember 2018).

Hardiyatmo, H.C. (2002). "Mekanika Tanah I - Edisi 3". Yogyakarta: Gadjah Mada University Press. , (2002). "Mekanika Tanah II - Edisi 3". Yogyakarta: Gadjah Mada University Press.

Hidayat, Anwar. (2013). "Uji Homogenitas". www.statistikian.com/2013/01/uji- homogenitas.html?m=1 (9 Desember 2018).

Nurgahanto, Terta. (2014). "Studi Perbandingan Beberapa Rumus Empiris Indeks Kompresi (Cc). Surakarta: Media Teknik Sipil UNS.

Rendon-Herrero.,O., "Universal Compression Index Equation", (1980), Journal of the Geotechnical Engineering Division, American Society of Civil Engineering,

Riduwan. (2012). "Dasar-dasar Statistika". Bandung: CV Alfabeta.

Rostikasari, A. (2016). "Korelasi Indeks Kompresi (Cc) Dengan Parameter Kadar Air Ilmiah (wn) Dan Indeks Plastisitas (IP)". Surakarta: Teknik Sipil Universitas Sebelas Maret Surakarta

Sugiyono. (2007). "Statistika untuk Penelitian". Bandung: CV Alfabeta.

Tantri K.S., dan Yerry K. Firmansyah. (2013). "The Empirical Correlation Using Linear Regression of Compression Index for Surabaya Soft Soil”. Surabaya ; Institut Teknologi Sepulus November

Slamet Widodo dan Abdelazim Ibrahim., (2012). "Estimation of Primary Compression Index (Cc) Using Physical Properties of Pontianak Soft Clay". International Journal of Engineering Research and Applications (IJERA) 